\title{
Effects of aerosols on precipitation in north-eastern North America
}

\author{
R. Mashayekhi and J. J. Sloan \\ Department of Earth and Environmental Sciences, University of Waterloo, Waterloo, ON, N2L 3G1, Canada
}

Correspondence to: J. J. Sloan (sloanj@uwaterloo.ca)

Received: 7 August 2013 - Published in Atmos. Chem. Phys. Discuss.: 29 October 2013

Revised: 11 April 2014 - Accepted: 11 April 2014 - Published: 26 May 2014

\begin{abstract}
The changes in precipitation in north-eastern North America caused by chemistry - and particularly anthropogenic aerosols - are investigated using the Weather Research Forecasting with Chemistry (WRF/Chem v3.2) model. The simulations were carried out for a five-month period from April to August 2009. The model results show that non-negligible changes in both convective and cloudresolved (non-convective) precipitation are caused by chemistry and/or aerosols over most parts of the domain. The changes can be attributed to both radiative and microphysical interactions with the meteorology. A chemistry-induced change of approximately $-15 \%$ is found in the five-month mean daily convective precipitation over areas with high convective rain; most of this can be traced to radiative effects. Total convective rain is greater than total non-convective rain in the domain, but a chemistry-induced increase of about $30 \%$ is evident in the five-month mean daily non-convective precipitation over the heavily urbanized parts of the Atlantic coast. The effects of aerosols on cloud microphysics and precipitation were examined for two particle size ranges, 0.039 $0.1 \mu \mathrm{m}$ and $1-2.5 \mu \mathrm{m}$, representing the nucleation and accumulation modes respectively. Strongly positive spatial correlation between cloud droplet number and non-convective rain are found for activated (cloud-borne) aerosols in both size ranges. Non-activated (interstitial) aerosols have a positive correlation with cloud droplet number and non-convective rain when they are small and an inverse correlation for larger sizes.
\end{abstract}

\section{Introduction}

The modification of climate by anthropogenic influences is the subject of intense public debate and extensive scientific research. Most of this interest is focussed on the global cli- mate, but regional effects are in some ways more important because they occur on a shorter timescale and can be quite intense. The so-called "urban heat island" effect is an example of this. It has been shown that thermal effects of megacities reach considerably beyond their borders (Wu et al., 2008) and also that precipitation increases occur downwind of the cities (Auvray and Bey, 2005; Tuccella et al., 2012). These results are relevant to predictions of the consequences of future urban growth in locations that do not, at present, have extremely high population densities. For example, the Toronto-Hamilton area had a 2011 census population of 6.5 million. This is expected to grow by more than $30 \%$ to 8.6 million in less than three decades (Xue et al., 2001). Similar or more rapid growth will occur in the cities of the north-eastern United States during the same period. In this and later publications, we intend to explore the possible effects of such increases in population density on the regional climate of north-eastern North America, with a focus on precipitation in southern Canada.

Aerosols are among the most important influences on precipitation. The precise mechanisms for these influences are complicated, but numerous observational and modelling studies have shown that precipitation is significantly influenced by atmospheric aerosols (Ackerman et al., 2000; Haywood and Boucher, 2000; Koren et al., 2005; Lohmann and Feichter, 2005; Penner et al., 2004; Ramanathan et al., 2001; Rosenfeld et al., 2006). Aerosol particles can affect cloud properties through a combination of radiative and microphysical effects (Rosenfeld et al., 2008). They can reduce convection by cooling the surface via attenuation of solar radiation (Ramanathan et al., 2001) and heat the upper atmosphere by absorption of infrared radiation (Haywood et al., 1999; Ramanathan et al., 2001). These particular effects combine to stabilize the atmosphere (Taubman et al., 2004) and reduce the generation of convective clouds (Koren et al., 2005). 
In addition to radiative effects, the aerosols also affect cloud microphysics by acting as cloud condensation nuclei (CCN) (Cotton and Pielke Sr., 2007). Increasing the number of CCN creates more droplets of smaller size and increases the cloud albedo (Twomey, 1977). This can slow the process of coalescence into raindrops, suppressing precipitation and prolonging the cloud lifetime (Albrecht, 1989; Haywood and Boucher, 2000). Based on the above description, both radiative and microphysical effects can cause reductions in precipitation. Our understanding of aerosol effects on precipitation, however, is still qualitative (IPCC, 2007). Some recent studies have reported an enhancement in precipitation due to aerosol effects (Bell et al., 2008; Givati and Rosenfeld, 2004; Khain et al., 2004; Lohmann and Hoose, 2009; Rosenfeld et al., 2002; Rudich et al., 2002), while others found aerosolinduced suppression (Andreae et al., 2004; Borys et al., 2003; Rosenfeld, 2000; Rosenfeld and Givati, 2006).

The response of cloud properties and precipitation to aerosols depends on many factors, including cloud types, relative humidity, atmospheric stability and aerosol characteristics such as hygroscopicity and index of refraction (Khain et al., 2005; Lynn et al., 2007; Tao et al., 2007; Williams et al., 2002). Consequently, a realistic understanding of the effects of aerosols on precipitation requires the use of models in which aerosols, meteorology, radiation and cloud microphysics couple in a fully interactive way. The Weather Research Forecasting with Chemistry (WRF/Chem) model (Grell et al., 2005) provides such an interactive coupling. WRF/Chem has been used successfully to simulate aerosolcloud interactions in a variety of situations (Chuang et al., 2011; Grell et al., 2005; Saide et al., 2012; Yang et al., 2011; Zhang et al., 2010a). Other previous work also found significant changes in precipitation due to the inclusion of aerosol feedback (Lynn et al., 2007; Zhang et al., 2010a, b). The accuracy of the model predictions, however, depends on many factors such as horizontal resolution, planetary boundary layer (PBL) turbulence parameterization and the quality of the emission inventory (McKeen et al., 2007). For this reason, the models must be carefully configured for the regions of application and their accuracy must be verified by comparison with measurements.

In this study, we have used both WRF and WRF/Chem (version 3.2) to explore the effect of chemistry on the amount and distribution of precipitation in north-eastern North America. The overall effects of chemistry can be deduced from a comparison of the results obtained from WRF with those from WRF/Chem, using identical meteorological parameterizations. An understanding of the causes for the observed differences, however, requires a more detailed analysis of the results using statistical and correlative methods.

We created temporally and spatially distributed emission fluxes for this work using the SMOKE emission-processing model with US and Canadian emission inventories. Much of this work involved the creation of surrogate files, which have the advantage of flexibility for scenario studies, which we hope to exploit in future work. In the following, however, we will discuss the influences of chemistry - and in particular aerosols - on precipitation as predicted by WRF/Chem. This will include an assessment of the accuracy with which the model can predict changes in precipitation and an examination of the important mechanisms involved. The latter include microphysical effects on non-convective precipitation and also thermal effects caused by cloud nucleation, which affect convective precipitation.

\section{Model configuration}

\subsection{WRF/Chem model description}

$\mathrm{WRF} / \mathrm{Chem}$ is an online-coupled meteorology-chemistryaerosol model being developed in a collaboration involving several organizations (NCAR, NOAA/NCEP, NOAA/ESRL and PNNL). Version 3.2 of WRF/Chem (Fast et al., 2006; Grell et al., 2005) was used for this study. WRF/Chem v3.2 has several choices for gas-phase chemical mechanisms and aerosol modules. The gas-phase chemistry in this study is based on the Carbon Bond Mechanism version Z (CBMZ) (Zaveri and Peters, 1999), which uses 67 prognostic species and 164 reactions in a lumped structure approach. The aerosol module used in this work is the Model for Simulating Aerosol Interactions and Chemistry (MOSAIC) aerosol scheme (Zaveri et al., 2008). The aerosol size distribution was defined using a sectional approach with four size-bins: $0.039-0.10 \mu \mathrm{m}, 0.10-1.0 \mu \mathrm{m}, 1.0-2.5 \mu \mathrm{m}$ and $2.5-$ $10 \mu \mathrm{m}$. The MOSAIC simulation calculates particle evolution via the major aerosol processes, including binary nucleation, coagulation, condensation and scavenging by cloud droplets, as well as wet and dry deposition. It also includes inorganic aerosol thermodynamic equilibrium and PM formation via aqueous-phase chemistry. Secondary organic aerosols (SOA) are not included in our model configuration. It is not possible at the present time to establish how this omission affects the results, but this point will be addressed in our next study, which will include this important component.

The bulk aqueous-phase chemistry of Fahey and Pandis (2001) is used. This includes 50 aqueous-phase species and 147 aqueous-phase processes (21 dissolution equilibria, 17 dissociation equilibria and 109 reactions) (Zaveri, 2008). Aerosol activation and re-suspension are based on the approach described by Chapman et al. (2009), using the droplet-activation parameterization of Abdul-Razzak and Ghan (2002), in which the aerosol activation is based on maximum supersaturation as calculated from explicitly resolved updraft velocities and aerosol properties. The interaction between aerosols, cloud microphysics, precipitation and radiation is described in Chapman et al. (2009), Fast et al. (2006) and Gustafson et al. (2007).

Table 1 lists the configuration options used for this study. Two sets of simulations (with and without chemistry) were 
carried out to assess the effects of chemistry and chemistryrelated aerosol processes on precipitation. The meteorological configuration was identical for both, but the chemistry options were all turned off for the meteorology-only (WRF) simulation. This results in the modification of the Lin microphysics scheme as follows. In the WRF simulations, the cloud water mixing ratio is predicted while the cloud droplet number is prescribed $\left(100 \mathrm{~cm}^{-3}\right)$. The autoconversion rate is then calculated based on the simple threshold approach (Kessler, 1969), i.e. the trigger for collision/coalescence of cloud droplets into rain drops is only based on the amount of cloud liquid water and no influence of cloud droplet number is considered. As a result, aerosols have no effect on the formation of precipitation in the WRF simulation. In the interactive (i.e. WRF/Chem) simulations, the prognostic treatment of cloud droplet number uses the double-moment version of the Lin et al. (1983) microphysics parameterization, whereby aerosols can be activated to form cloud droplets. In this case, the autoconversion rate of cloud droplets to rain drops is based upon the droplet number, droplet size spectrum, droplet mass and cloud liquid water content (Liu et al., 2005). Thus, aerosols affect the formation of clouds and precipitation by activation of $\mathrm{CCN}$ as the main source of cloud droplets.

The model domain covers the north-eastern part of North America with a $12 \times 12 \mathrm{~km}^{2}$ horizontal grid; it includes 31 vertical levels extending up to approximately $16 \mathrm{~km}$ above mean sea level. We carried out simulations for a five-month period from April to August 2009. Weather archives confirm the absence of unusual meteorology during this period, which is a necessary condition for the purpose of this study. We chose the summer period because it is the best season to study convective vs. non-convective rain, which is an important focus of the work. A corresponding winter study was not carried out because the coupling of prognostic aerosols to ice nuclei is not properly included in the WRF/Chem microphysics scheme used for this work; this would reduce the simulation accuracy in our domain. The initial and lateral boundary conditions for meteorological parameters were obtained from the three-hourly North American Regional Reanalysis (NARR) dataset.

The initial and boundary conditions for trace gases and particulate species were taken from the MOZART-4 global model output at $3 \mathrm{~h}$ time intervals (Emmons et al., 2010). The model simulations were re-initialized every 3.5 days and the first $12 \mathrm{~h}$ of each run were discarded, allowing for a $12 \mathrm{~h}$ spinup period for the meteorology. Simulations carried out at the beginning of the project showed that negligible changes result from using a 2 day re-initialization period. The chemistry initialization was obtained from the previous run (i.e. the output from the previous simulation was used as input for the next one).

\subsection{Emission processing}

Biogenic and anthropogenic emissions from various sources are considered separately in this study. Anthropogenic emissions for gases and aerosol particles were pre-processed using the Sparse Matrix Operator Kernel Emissions (SMOKE) modelling system, version 2.7, which is developed and maintained by the United States Environmental Protection Agency (US EPA) and the Carolina Environmental Program (CEP) of the University of North Carolina (Houyoux and Vukovich, 1999). SMOKE is, inter alia, an emission processing system designed to convert raw emission inventory data to gridded, speciated, hourly emission rates suitable for input to Air Quality Models.

We used the total annual, province-based Canadian emission inventory for the year 2006 provided by Environment Canada and the corresponding county-based US inventories for 2008 from the EPA National Emissions Inventory (NEI) (http://www.epa.gov/ttn/chief/net/2008inventory.html). Processing of these inventory data using SMOKE provided chemical speciation and temporal and spatial allocation for area, point and mobile (both on-road and non-road) emission sources separately. Many of the emission rates for this study were developed using surrogate tools with SMOKE and the meteorology used for the calculation. For area and mobile sources, the province- or county-total emissions were allocated to the WRF/Chem model grid cells through the use of gridding surrogates. We created 62 surrogate files for the US and 35 for Canada by processing a set of GIS shape files using the Surrogate Generator Tool, which can be found at http://www.ie.unc.edu/cempd/projects/mims/ spatial/srgtool/SurrogateToolUserGuide.v3.6.htm. The surrogate files contain information on population, construction, agriculture, land use, etc., which can be modified for scenario studies. This approach has two advantages (Yerramilli et al., 2010; Zhang et al., 2010a): it produces accurate results, as borne out by the biases shown in Table 2 and it provides a convenient way to vary the emissions for scenario studies, which are planned for future publications.

Biogenic emissions were calculated online using the Model of Emissions of Gases and Aerosols from Nature (MEGAN) (Guenther et al., 2006). MEGAN is designed to give the net emission of gases and aerosols from terrestrial ecosystems into the atmosphere. It has been fully coupled into WRF/Chem to allow the online calculation of biogenic precursor emissions subject to the vegetation cover and existing meteorological conditions (temperature and solar radiation) at the time of the calculation (Grell et al., 2005). The online calculation of natural dust and sea-salt emissions based on Peckham et al. (2011) and Shaw et al. (2008), respectively, are also included. 
Table 1. The WRF/Chem configuration options used in this study.

\begin{tabular}{|c|c|c|}
\hline Atmospheric processes & Model option & Reference \\
\hline \multicolumn{3}{|l|}{ Meteorology } \\
\hline Longwave radiation & RRTM & Mlawer et al. (1997) \\
\hline Shortwave radiation & Goddard & Chou et al. (1998) \\
\hline Land surface model & Noah LSM & Chen and Dudhia (2001) \\
\hline Boundary layer & YSU & Hong et al. (2006) \\
\hline Cumulus & Grell 3D & Grell and Devenyi (2002) \\
\hline Cloud microphysics & Lin et al & Lin et al. (1983) \\
\hline \multicolumn{3}{|l|}{ Chemistry } \\
\hline Photolysis & Fast-J & Wild et al. (2000) \\
\hline Gas-phase chemistry & CBM-Z & Zaveri and Peters (1999) \\
\hline Aerosol scheme & MOSAIC & Zaveri et al. (2008) \\
\hline Chemical BC & MOZART 4 & Emmons et al. (2010) \\
\hline Anthropogenic emissions & Processed by SMOKE 2.7 & Houyoux and Vukovich (1999) \\
\hline Biogenic emissions & MEGAN & Guenther et al. (2006) \\
\hline
\end{tabular}

Table 2. Summary of the evaluation of WRF/Chem simulations from April to August 2009 by comparison with ground-based meteorological and chemical measurements.

\begin{tabular}{|c|c|c|c|c|c|c|c|c|}
\hline & \multirow[t]{2}{*}{ Variables } & \multirow[t]{2}{*}{ Month } & \multirow[t]{2}{*}{ Stations } & \multirow[t]{2}{*}{ Mean Obs } & \multirow[t]{2}{*}{ Mean Model } & \multirow[t]{2}{*}{ RMSE } & \multicolumn{2}{|l|}{ Bias } \\
\hline & & & & & & & Mean & $\%$ \\
\hline \multirow{15}{*}{ Meteorology } & Total Daily Rain $\left(\mathrm{mm} \mathrm{day}^{-1}\right)$ & Apr & 105 & 2.50 & 2.84 & 4.56 & 0.34 & 13.6 \\
\hline & & May & 105 & 2.25 & 2.66 & 4.57 & 0.37 & 16.4 \\
\hline & & Jun & 105 & 2.74 & 3.52 & 7.03 & 0.84 & 30.7 \\
\hline & & Jul & 105 & 3.39 & 4.42 & 8.01 & 1.03 & 30.4 \\
\hline & & Aug & 105 & 3.38 & 4.12 & 8.29 & 0.72 & 21.3 \\
\hline & $T_{2}\left({ }^{\circ} \mathrm{C}\right)$ & Apr & 95 & 3.15 & 4.51 & 3.24 & 1.27 & 40.3 \\
\hline & & May & 95 & 8.49 & 10.26 & 3.81 & 1.77 & 20.8 \\
\hline & & Jun & 95 & 14.32 & 15.06 & 3.41 & 0.83 & 5.8 \\
\hline & & Jul & 95 & 16.12 & 16.68 & 3.20 & 0.57 & 3.5 \\
\hline & & Aug & 95 & 16.77 & 17.75 & 3.04 & 0.99 & 5.9 \\
\hline & Wind Speed at $10 \mathrm{~m}_{\left(\mathrm{m} \mathrm{s}^{-1}\right)}$ & Apr & 95 & 4.38 & 4.81 & 2.23 & 0.42 & 9.6 \\
\hline & & May & 95 & 4.18 & 4.48 & 2.37 & 0.31 & 7.4 \\
\hline & & Jun & 95 & 3.56 & 3.98 & 2.07 & 0.43 & 12.1 \\
\hline & & Jul & 95 & 3.41 & 4.04 & 2.11 & 0.64 & 18.8 \\
\hline & & Aug & 95 & 3.40 & 4.14 & 2.14 & 0.73 & 21.5 \\
\hline \multirow[t]{10}{*}{ Chemistry } & Ozone (ppb) & April & 109 & 36.66 & 27.46 & 13.54 & -9.19 & -25.1 \\
\hline & & May & 109 & 32.00 & 25.49 & 15.57 & -6.55 & -20.5 \\
\hline & & Jun & 109 & 26.01 & 28.29 & 11.29 & 2.28 & 8.8 \\
\hline & & Jul & 109 & 21.08 & 25.78 & 10.79 & 4.73 & 22.4 \\
\hline & & Aug & 109 & 23.36 & 25.73 & 12.96 & 3.37 & 14.4 \\
\hline & $\mathrm{PM}_{2.5}\left(\mu \mathrm{g} \mathrm{m}^{-3}\right)$ & Apr & 64 & 5.08 & 6.14 & 6.04 & 1.09 & 21.5 \\
\hline & & May & 64 & 5.84 & 7.48 & 7.86 & 1.64 & 28.1 \\
\hline & & Jun & 64 & 6.02 & 7.87 & 8.67 & 1.88 & 31.2 \\
\hline & & Jul & 64 & 6.73 & 6.23 & 5.63 & -0.50 & -7.4 \\
\hline & & Aug & 64 & 9.39 & 7.42 & 8.10 & -1.99 & -21.2 \\
\hline
\end{tabular}




\section{Model evaluation}

In order to establish the accuracy of the model's parameterizations and estimate the value of its scenario predictions, the WRF/Chem simulations were evaluated by comparison with available meteorological and chemical observations. Hourly meteorological measurements including $T_{2}$ (the temperature at $2 \mathrm{~m}$ above the surface), total precipitation and wind speed at $10 \mathrm{~m}$ were obtained from the National Climate Data and Information Archive (http://www.climate.weatheroffice.gc.ca) for Canada and from the Clean Air Status and Trends Network (CASTNET; http://epa.gov/castnet/javaweb/index.html) for the US. Hourly observations of surface $\mathrm{PM}_{2.5}$ and ozone concentrations were provided by the Canadian National Air Pollution Surveillance Network (NAPS; http://www.ec.gc.ca/ natchem/default.asp?lang=en $\&$ n=EE0E2169-1) and by the United States Environmental Protection Agency (EPA; http: //www.epa.gov/airdata).

Table 2 summarizes the month-by-month statistical evaluations for the meteorological variables and chemical species averaged over all stations for each month from April to August 2009. Comparisons of the model predictions and measurements for temperature and total daily precipitation are shown on maps of the model domain in Fig. 1a and b respectively. The measured results are shown inside the coloured circles, which also give the locations of the observation stations. Figure 1a shows that the spatial distribution of $T_{2}$ is well reproduced by the model, despite a moderate overprediction, especially for the spring months, that is evident in Table 2. The mean positive bias in $T_{2}$ ranges from $+1.27^{\circ} \mathrm{C}$ (40\%) in April to $+0.57^{\circ} \mathrm{C}(3.5 \%)$ in July. These errors occur mostly in the high mid-latitudes, where the temperatures are most variable in the spring. They could be due to an inadequate description of the details of the large-scale polar circulation, which are not captured in our limited domain, or to a poor representation of the PBL. The model gives a much better description in the warmer months and in the southern part of the domain, where temperature variations are smaller.

Figure $1 \mathrm{~b}$ shows that the simulated total daily precipitation agrees quite well with observations everywhere in the domain except for an over-prediction in parts of the southernmost states of the US. that is evident in Table 2, which shows that there is a systematic positive bias for daily precipitation, with the best performance in April (mean bias of $+13.6 \%$ ) and worst in July (mean bias of $+30.3 \%$ ). The model bias increases as the observed precipitation increases from April to July. Examination of the hourly time series for the individual months shows that most of the precipitation in the areas having the largest errors occurs during localized, intense convective rain events, which are difficult to reproduce at a $12 \mathrm{~km}$ grid spacing. Data included in the Supplement show examples of this for the Edgar Evins station, which is in Tennessee, $\left(36.04^{\circ} \mathrm{N}, 85.73^{\circ} \mathrm{W}\right)$. The comparison also might be affected by poor measurement statistics
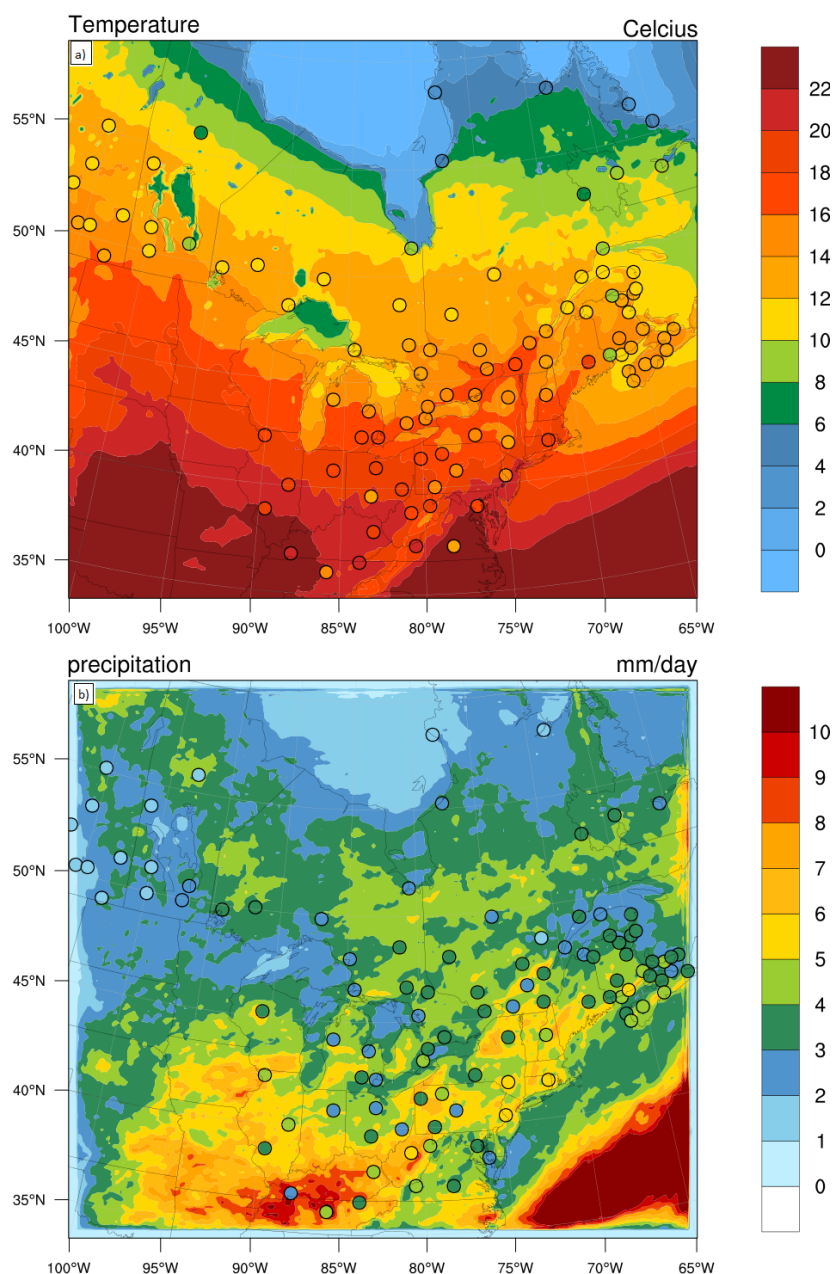

Figure 1. Observed and simulated $2 \mathrm{~m}$ temperature (a) and total daily precipitation (b) averaged for five months (AprilAugust 2009). Measurements are shown as circles with the same colour scale as the simulations.

due to the small number $(\sim 10)$ of measurements in the part of the domain having the largest errors, combined with the relatively short duration of these convective storms. While we are concerned by these biases, we note that they are comparable to or smaller than those reported previously in similar studies with WRF/Chem (Chuang et al., 2011; Zhang et al., 2010b) and also with Community Multiscale Air Quality Model (CMAQ) (Wang et al., 2009; Wu et al., 2008). Nevertheless, this result might indicate limitations in the Grell 3-D convective scheme, which could be a matter for future examination.

Hourly time series of the simulated and observed $T_{2}$, wind speed, $\mathrm{O}_{3}$ and $\mathrm{PM}_{2.5}$ are given in Fig. 2 from April to August 2009 at NAPS station number 60430. This station is located in Toronto and is classified as urban, thus providing a severe test for the model. The model captures the $T_{2}$ diurnal cycle well at this location; the small (3.5\%) error in this case 


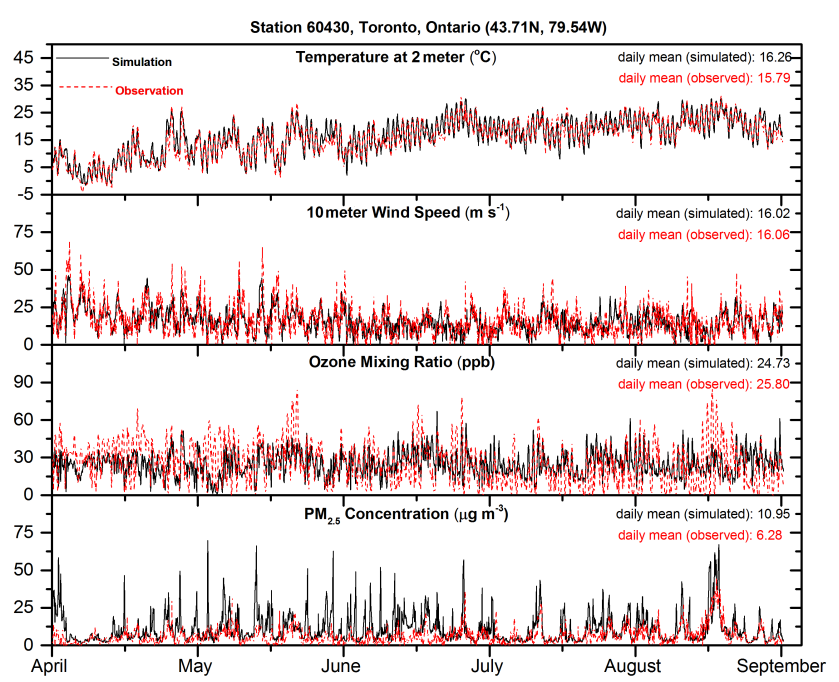

Figure 2. Simulated and observed time series of hourly temperature at $2 \mathrm{~m}$ above the surface, wind speed at $10 \mathrm{~m}$, hourly surface ozone and $\mathrm{PM}_{2.5}$ concentrations from April to August 2009 at station 60430 located in Toronto.

is largely due to over-prediction of the minimum nighttime temperatures.

The model reproduces the $10 \mathrm{~m}$ wind speed with a range of mean biases from $+7.4 \%$ in May to $+21.4 \%$ in August. Better overall agreement is found in the spring months of April and May, when the observed wind speeds are slightly higher. Also, the daily mean wind speeds are well simulated, so the performance is reasonable for a regional scale model. Similar or somewhat larger biases in wind speed predictions have been reported previously in comparable WRF/Chem studies (Chuang et al., 2011; Zhang et al., 2010b).

The monthly mean surface ozone is underestimated in the spring months, with mean biases of -25 and $-20 \%$ in April and May, respectively and overestimated during the warmer months by $8.8 \%$ (June), $22.4 \%$ (July) and $14.4 \%$ (August). Springtime underestimation and summertime overestimation of surface ozone also have been reported for similar WRF/Chem studies in both North America and Europe (Auvray and Bey, 2005; Tuccella et al., 2012; Yerramilli et al., 2010; Zhang et al., 2010b). Various factors are thought to contribute to these uncertainties, including the misrepresentation of background ozone through incorrect lateral boundary values and an inadequate description of photolysis radiation. We explored the effects of boundary conditions in two sets of simulations (not shown here), one of which used static default profiles and the other used time-dependent MOZART simulations. Not surprisingly, better performance (less underestimation) was found when MOZART data were used, so we used these for the results that we report here. It is beyond the scope of the present study to examine the causes for the remaining errors, but their seasonal dependence suggests the possibility of problems with radiative transfer due to the
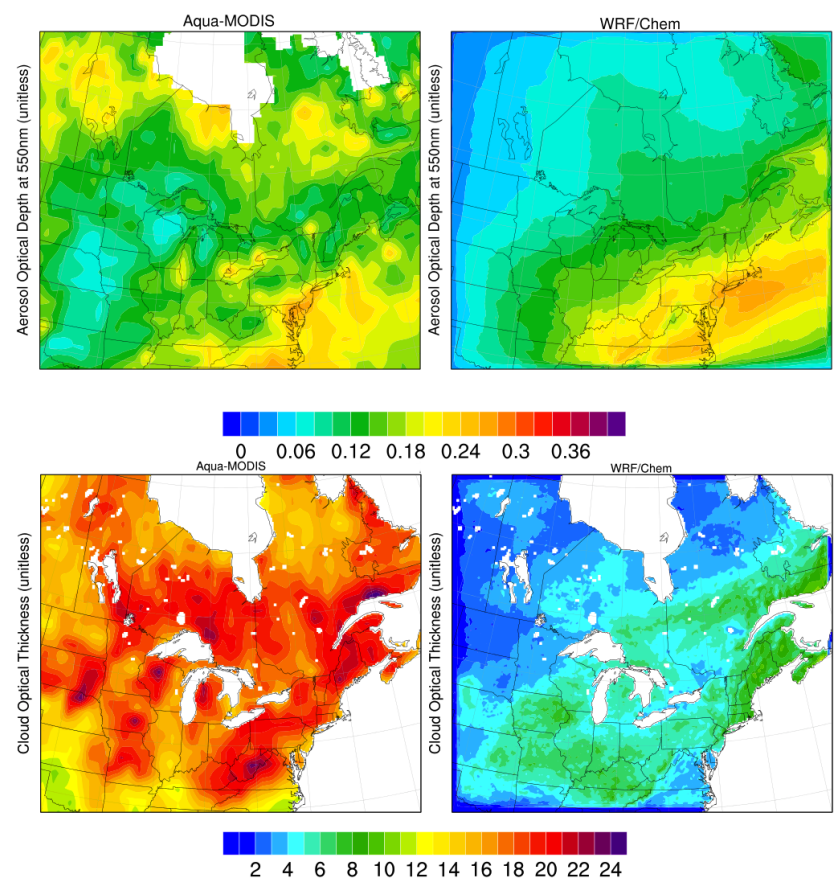

Figure 3. Comparison of MODIS-Aqua products and WRF/Chem three-month average (JJA) total column Aerosol Optical Depth at $550 \mathrm{~nm}$ (top) and Cloud Optical Thickness (bottom).

simulated cloud cover, which would affect the photochemistry.

Table 2 shows that monthly mean $\mathrm{PM}_{2.5}$ concentration is over-predicted in April, May and June by 21.4, 28.1 and $31.2 \%$ respectively, while the other two months have underestimations of -7.4 and $-21.2 \%$ respectively. As noted earlier, these results do not include SOA.

In order to assess the model performance in aerosol-related simulations, we compared the Aerosol Optical Depth (AOD) and Cloud Optical Thickness (COT) results from the model with the corresponding Moderate Resolution Imaging Spectroradiometer (MODIS; Aqua) level 3 products. The MODIS level 3 values are derived from the level 2 aerosol and cloud products by averaging the level 2 retrievals $(10 \mathrm{~km}$ spatial resolution) across each $1^{\circ}$ by $1^{\circ}$ grid box of the level 3 product. Figure 3 shows the comparison of the summer (JJA) average COT and AOD at $550 \mathrm{~nm}$ derived from MODIS with the corresponding $\mathrm{WRF} / \mathrm{Chem}$ results.

The comparison shows that the agreement between the simulated and measured AOD is reasonably good in the south-eastern part of the domain, but there is a significant underestimation in the north-western part. The south-eastern part of the domain is both heavily populated and coastal, so the aerosol there is dominated by dust, anthropogenic emissions and sea salt. The north-east, on the other hand, has a very sparse population and almost all emissions are biogenic. The model configuration used for this work did not have a secondary organic aerosol product and an underestimation in 

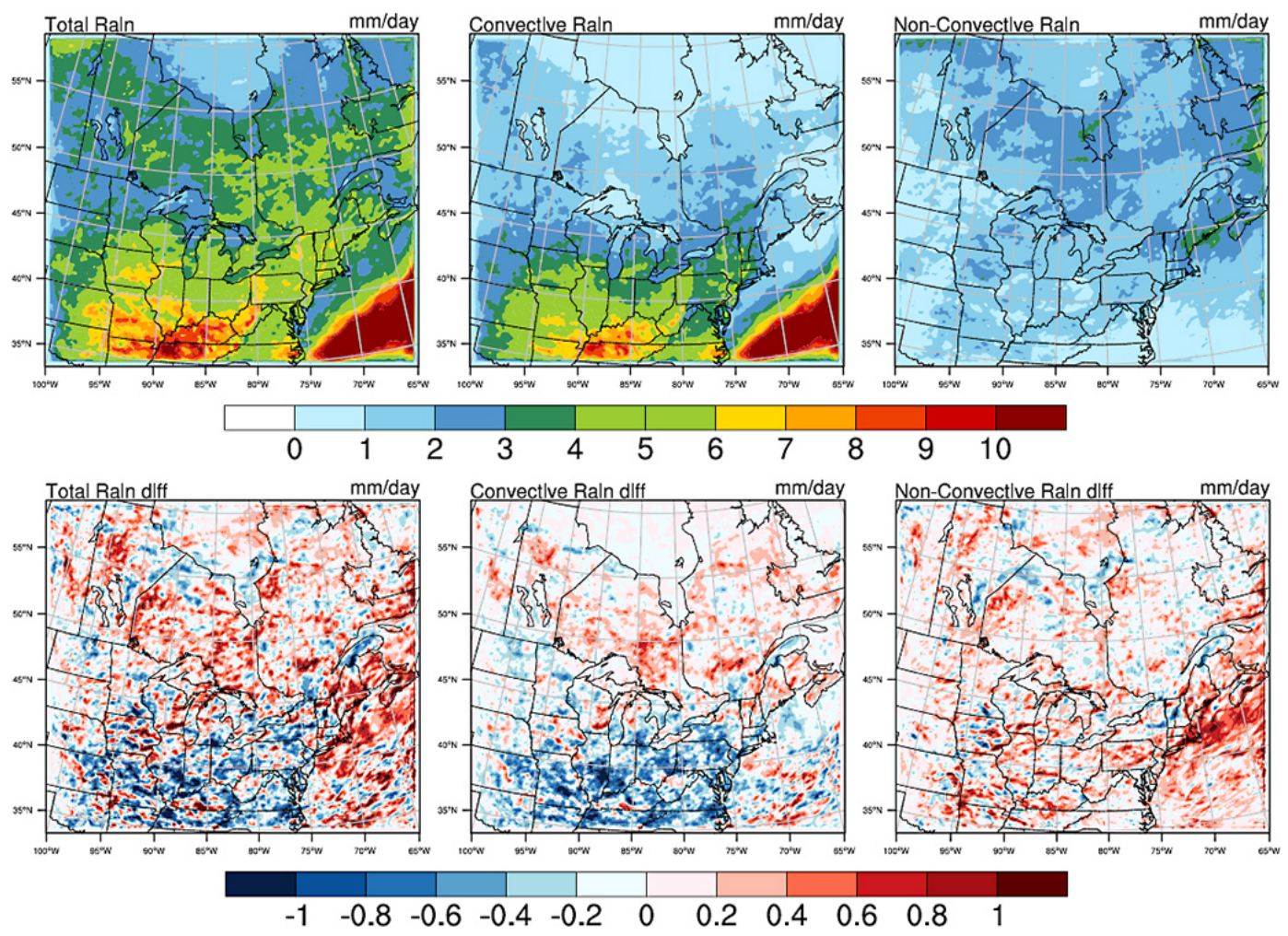

Figure 4. Spatial distribution of five month mean (April-August, 2009) simulated total daily precipitation (left), convective (centre) and non-convective rain (right) by WRF/Chem (top) and the difference (WRF/Chem - WRF) (bottom).

heavily forested regions such as this is expected. The large size of the discrepancy shows the importance of SOA in such regions. The model overestimates the marine AOD over the coastal waters somewhat, but the discrepancy in this case is not large. The satellite retrieval algorithms, which are based on light scattering, depend strongly on particle size and the 4-bin version of MOSAIC used in the model involves approximations in this quantity, thereby contributing to the uncertainty in the predicted AOD. Within these constraints, the agreement is reasonable.

The model reproduces the general spatial distribution of the observed COT reasonably well, but it underestimates the absolute values obtained from the MODIS measurement. The model also underestimates the cloud liquid water path (not shown here). In this case, the absolute comparison is not expected to be quantitative because both measurement and prediction are subject to significant uncertainties. The measured COT depends on the sensor resolution, cloud inhomogeneity and microphysical assumptions involved in the retrieval, whereas the prediction depends on the microphysics scheme, the model resolution and the radiative transfer assumptions. In view of this, agreement in the spatial distribution is expected, but failure to duplicate the absolute value is not so surprising. The fact of the underestimation, however, combined with the positive bias reported in Table 2 for total daily precipitation during these months, suggests that the predicted particle sizes are too large, resulting in higher precipitation rates and lower COT and cloud liquid water path. Similar results reported by Saide et al. (2012) stem from biases in wet deposition parameterization, but a contribution from microphysics scheme can not be ruled out.

On the basis of these results, we conclude that the WRF/Chem configuration used here provides a good description of the meteorological parameters that are the focus of this study, but further refinements are required to improve the quantitative accuracy. In particular, it is important to include SOA and its interaction with aqueous chemistry if a quantitative prediction of precipitation rates in this domain is to be achieved.

\section{Results and discussion}

Figure 4 shows the spatial distribution of the five-month (April to August 2009) mean daily precipitation simulations. The total daily precipitation (left plot) is the sum of the convective (centre plot) and non-convective (right plot) precipitation. Convective rain is the sub-grid-scale rainfall parameterized by the convective cumulus scheme (the Grell 3-D option for convective cloud formation), which does not include aerosol cloud nucleation. The non-convective part is 


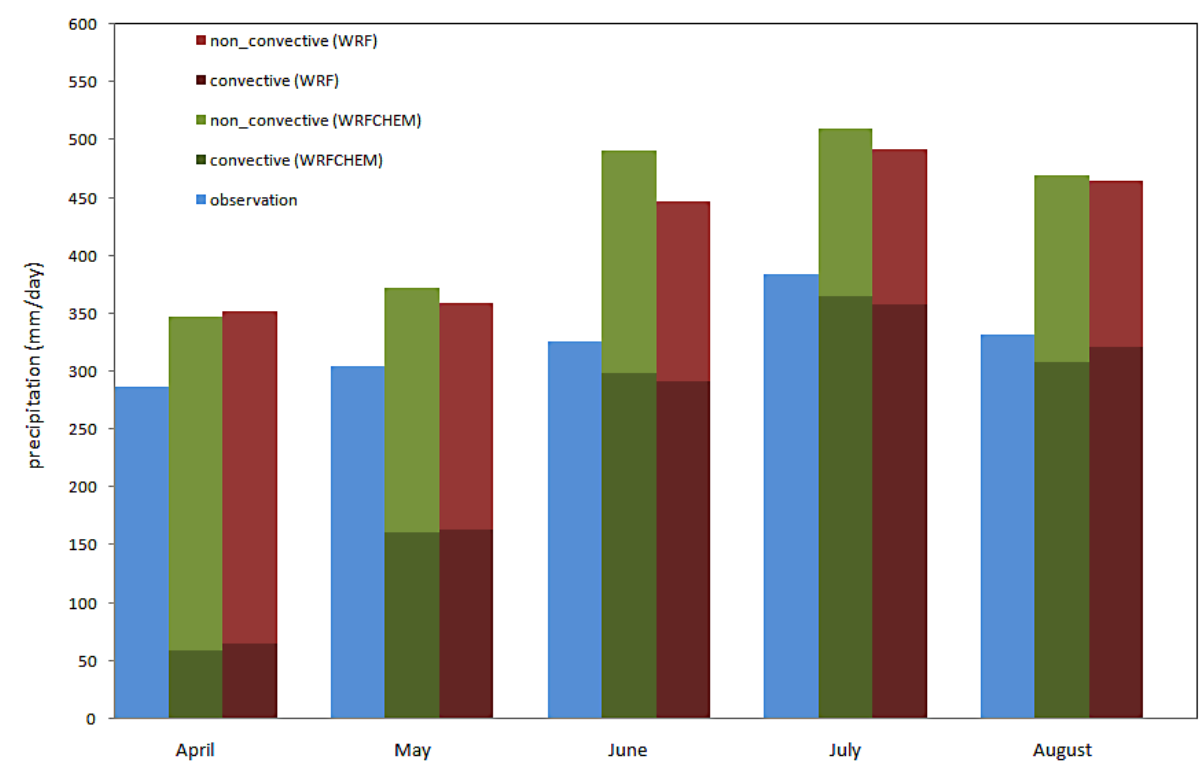

Figure 5. Comparison of observed total daily precipitation integrated over all the monitoring sites shown in Fig. 1 with the convective and non-convective precipitation simulated by WRF and WRF/Chem.

the grid-scale precipitation, calculated explicitly through the cloud microphysical processes in WRF/Chem.

For convenience, we distinguish between thermal and microphysical processes in describing the effects of aerosols on convective and non-convective precipitation respectively. In making this distinction, we are aware that convection affects resolved clouds through processes such as vertical transport of water vapour and the presence of resolved clouds affects convection. Also, aerosols have indirect effects on cumulus formation by thermal mechanisms that include direct radiative transfer and their formation of resolved clouds. It is not possible, therefore, to make a clear distinction between aerosol thermal effects and aerosol microphysics on the formation of resolved clouds, but the largest effects of aerosols on convective rain are thermal in origin and of course, their largest effects on resolved clouds are microphysical.

Figure 5 quantifies the seasonal contributions of convective and non-convective rain for both WRF and WRF/Chem. It shows the monthly mean precipitation amounts from the different precipitation types integrated over all the monitoring sites indicated previously by circles in Fig. 1. This shows that WRF/Chem predicts more non-convective rain than WRF in most cases. It is evident that the non-convective precipitation is more significant during April and May, while convective rain dominates in warmer periods due to greater tropospheric instability in the summer. The positive bias in the simulated total rain increases in warmer months as the convective precipitation increases - an observation that has been reported previously (Chen et al., 1998; Zhang et al., 2010b). The most possible cause of this seasonal dependence in the model bias for convective precipitation is the highly localized, rapidly varying nature of the latter, which makes the comparison of point measurements with predictions that are averaged over $12 \mathrm{~km}$ grid cells particularly difficult.

As shown in Figs. 1 and 4, the total daily precipitation averaged over five months has maxima over the central parts of the United States with the highest amounts of about $9 \mathrm{~mm} \mathrm{day}^{-1}$ in Kentucky and Tennessee. (Similarly heavy average rainfall of more than $10 \mathrm{~mm} \mathrm{day}^{-1}$ also occurs off the Atlantic coast.) Comparing the convective and non-convective plots in Fig. 4 shows that the heavy rainfall in the southern part of the domain is almost all convective and that the highest non-convective values (about 2-3 mm day ${ }^{-1}$ ) occur further north, over central and south-eastern Canada.

A simple way to estimate the magnitude of the effects caused by the addition of chemistry to the simulation is to compare the results from WRF/Chem with those with the same WRF configuration, with the chemistry turned off. The lower panels in Fig. 4 show the differences obtained when the WRF (i.e. no chemistry) predictions of the five months mean precipitation are subtracted from those of WRF/Chem and broken down as total, convective and non-convective in the left, centre and right plots, respectively. The (WRF/ChemWRF) difference plots for convective precipitation show that it is diminished in the southern part of the domain and increased in the northern part when chemistry is included. The effects of chemistry on non-convective rain have a higher degree of spatial variability, but it appears that the inclusion of chemistry causes a small, but widespread increase in nonconvective rain in the southern part of the domain and a pronounced increase near the heavily populated urban areas in the north-eastern US coast.

The results shown in Fig. 4 can be interpreted in terms of models of aerosol-cloud interactions that have been 

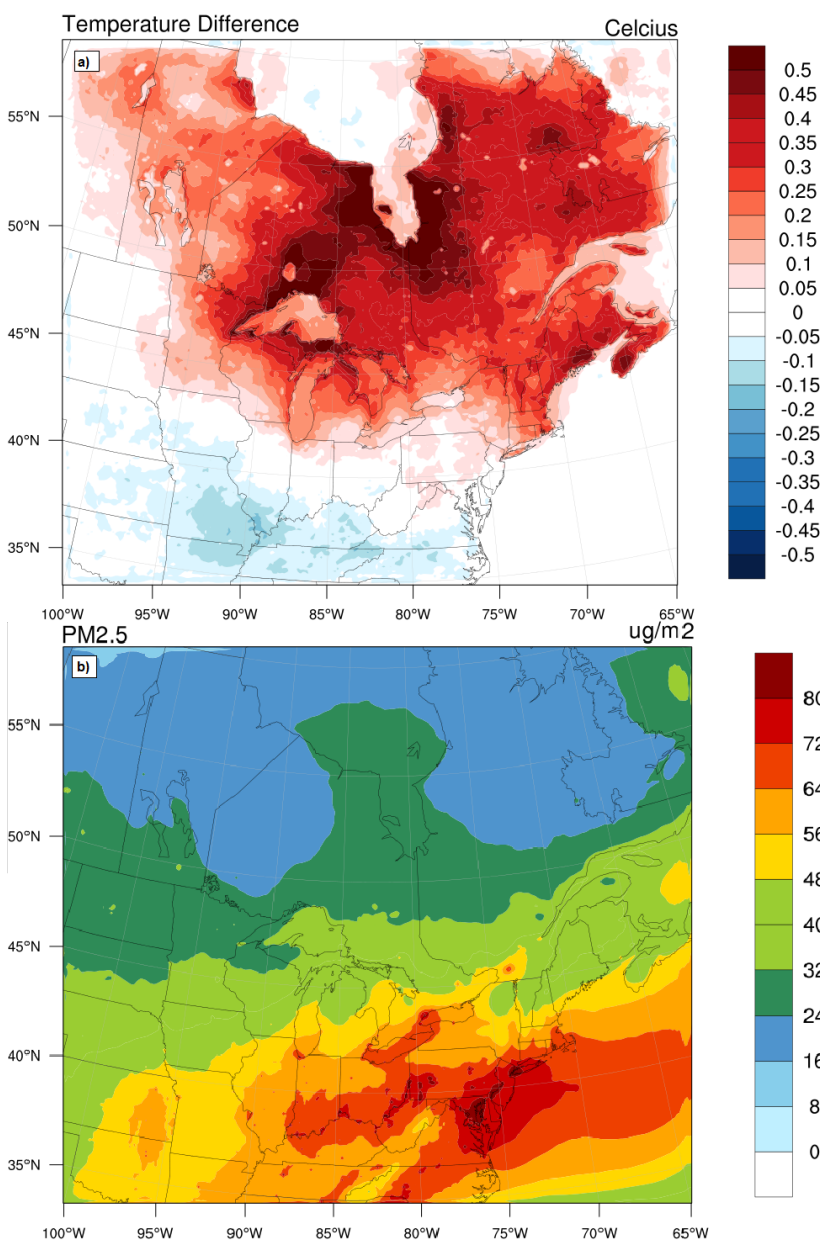

Figure 6. Simulated spatial distributions of: (a) five month mean (April to August 2009) WRF/Chem-WRF Temperature at $2 \mathrm{~m}$; (b) WRF/Chem column integrated mass concentration of $\mathrm{PM}_{2.5}$

developed over the past few years. As shown in the central panels of Fig. 4, there is a chemistry-induced decrease (around $-1 \mathrm{~mm} \mathrm{day}^{-1}$ or approximately $-15 \%$ ) in convective precipitation over the areas with high convective rain. This can be associated with additional surface cooling when chemistry is included, as is shown in the temperature difference plot in Fig. 6a. This surface cooling occurs predominantly in regions of high column-integrated $\mathrm{PM}_{2.5}$ (see Fig. 6b), due to a combination of direct light scattering by the aerosols and by clouds nucleated by the aerosols. Conversely, warming occurs over southern Canada and northern US - an effect that has also been reported by Zhang et al. (2010a). Our simulations (not shown here) show that light-absorbing aerosols such as black carbon are more prevalent at high altitudes in the northern part of the domain. These cause warming at elevated altitudes, which results in a reduction of the cloud optical thickness and a consequent increase in the WRF/Chem-WRF $2 \mathrm{~m}$ temperature difference in that part of the domain. This temperature effect is also consistent with
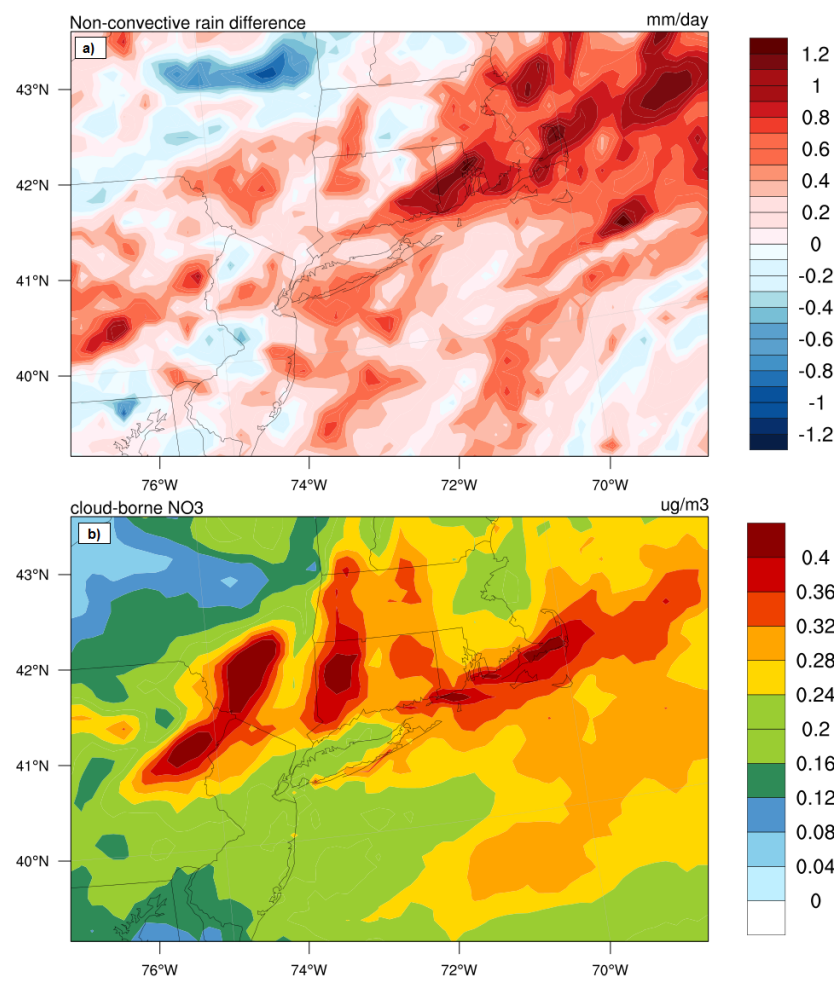

Figure 7. Spatial distributions of five month mean (April to August 2009) non-convective WRF/Chem-WRF rain difference (a) and the column integrated cloud-borne nitrate (b).

the increase in the (WRF/Chem-WRF) difference in convective rain in the upper part of the domain that is seen in Fig. 4. The two central panels of Fig. 4 also show that there is very little overall change in the very heavy convective rainfall over the Atlantic with the inclusion of chemistry - an observation that is also consistent with the fact that sea-surface temperature is nearly invariant to inclusion of chemistry in the model (Fig. 6b).

The effects of chemistry on non-convective rain are also consistent with our understanding of the effects of aerosols on precipitation. Figure 4 shows that there is less nonconvective rain in the southern part of the domain (top panel), but the chemistry-induced increase in non-convective rain (bottom panel) is larger there than in the northern part. Consistent with the above arguments, higher aerosol concentrations (see Fig. 6b) in the southern part of the domain cause decreased convective precipitation because of cooling due to direct effects and also by nucleating clouds that cause additional surface cooling. Higher aerosol concentrations along the eastern seaboard cause increased non-convective precipitation due to cloud nucleation in a region of elevated humidity.

This pronounced chemistry-induced increase in nonconvective precipitation (around $+30 \%$ ) is evident in the difference plot of the heavily urbanized parts of the Atlantic coast (lower right panel, Fig. 4). To understand its origin, 

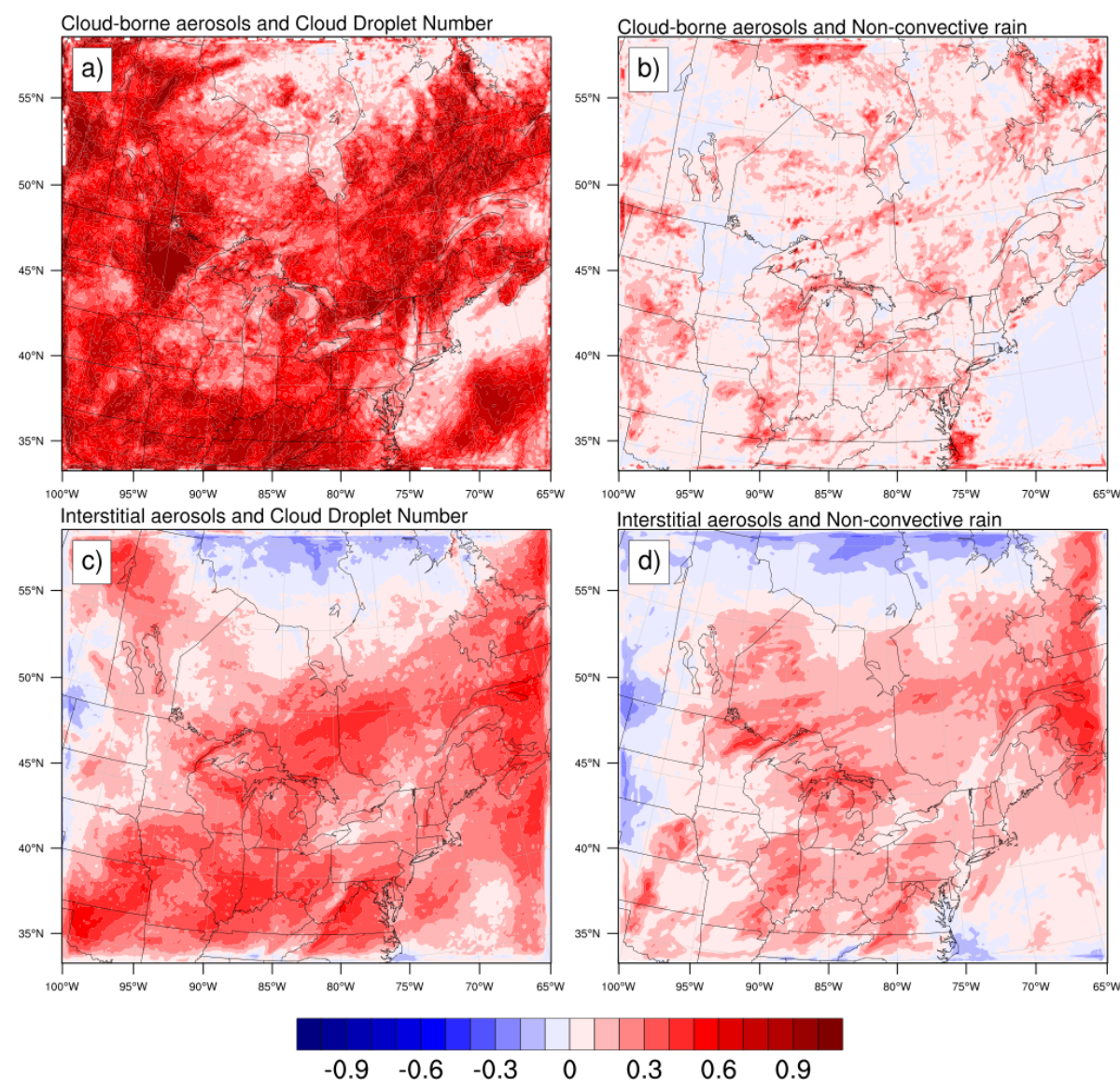

Figure 8. Correlation between simulated WRF/Chem cloud droplet number (left) and non-convective rain (right), with column-integrated cloud-borne (top) and interstitial (bottom) for size range $0.039-0.1 \mu \mathrm{m}$.

we took advantage of the explicit separation between activated (cloud-borne) aerosols and the remaining (interstitial) particles in the WRF/Chem output and plotted the spatial correlations of the various aerosol types with non-convective precipitation. The high-resolution plots in Fig. 7 show the result of this analysis. Figure 7a shows there is a strong increase in non-convective precipitation downwind of the heavily populated areas. (In this region, the predominant wind direction is toward the east-north-east.) More detailed spatial correlations (not shown) indicated that small nitrate aerosols in the size range $0.1-1.0 \mu \mathrm{m}$ had the highest spatial correlation with non-convective rain. Figure $7 \mathrm{~b}$ shows the column integrated cloud-borne nitrate mass concentration. The correlation with increased non-convective rain is clear, a result that has also been reported previously (Ntelekos et al., 2009). The bulk aqueous-phase chemistry scheme used here (Fahey and Pandis, 2001) includes oxidation of dissolved S(IV) and the uptake of nitric acid, hydrochloric acid, ammonia and other common anthropogenic trace gases. Uptake of soluble species and the resulting change in the water activity can lead to droplet growth in conditions of higher relative humidity, such as those in Fig. 7, and thus to an increase in precipi- tation. from this we conclude that anthropogenic emissions from highly populated and industrialized locations have nonnegligible influences on regional cloud formation and precipitation.

In order to elucidate further the possible microphysical influences of aerosols on precipitation, we analysed the spatial correlation coefficients for the relevant variables. While correlations do not prove causality, they give good circumstantial evidence on which to base hypotheses (that will guide future experiments). The spatial correlation coefficients were calculated separately for activated (cloud-borne) particles and non-activated (interstitial) particles. Total aerosol mass concentrations were used for this part of the study; no chemical speciation was attempted. The results are shown in Figs. 8 and 9. The spatial correlation of column-integrated aerosols with cloud droplet number and non-convective precipitation is given in Fig. 8 for the size range $0.039-0.10 \mu \mathrm{m}$ and in Fig. 9 for the $1.0-2.5 \mu \mathrm{m}$ size range.

Not surprisingly, there is a strong positive correlation between cloud droplet number and cloud-borne aerosols of both sizes - i.e. the aerosols nucleate new cloud droplets or dissolve in existing cloud droplets or both. A positive, but 

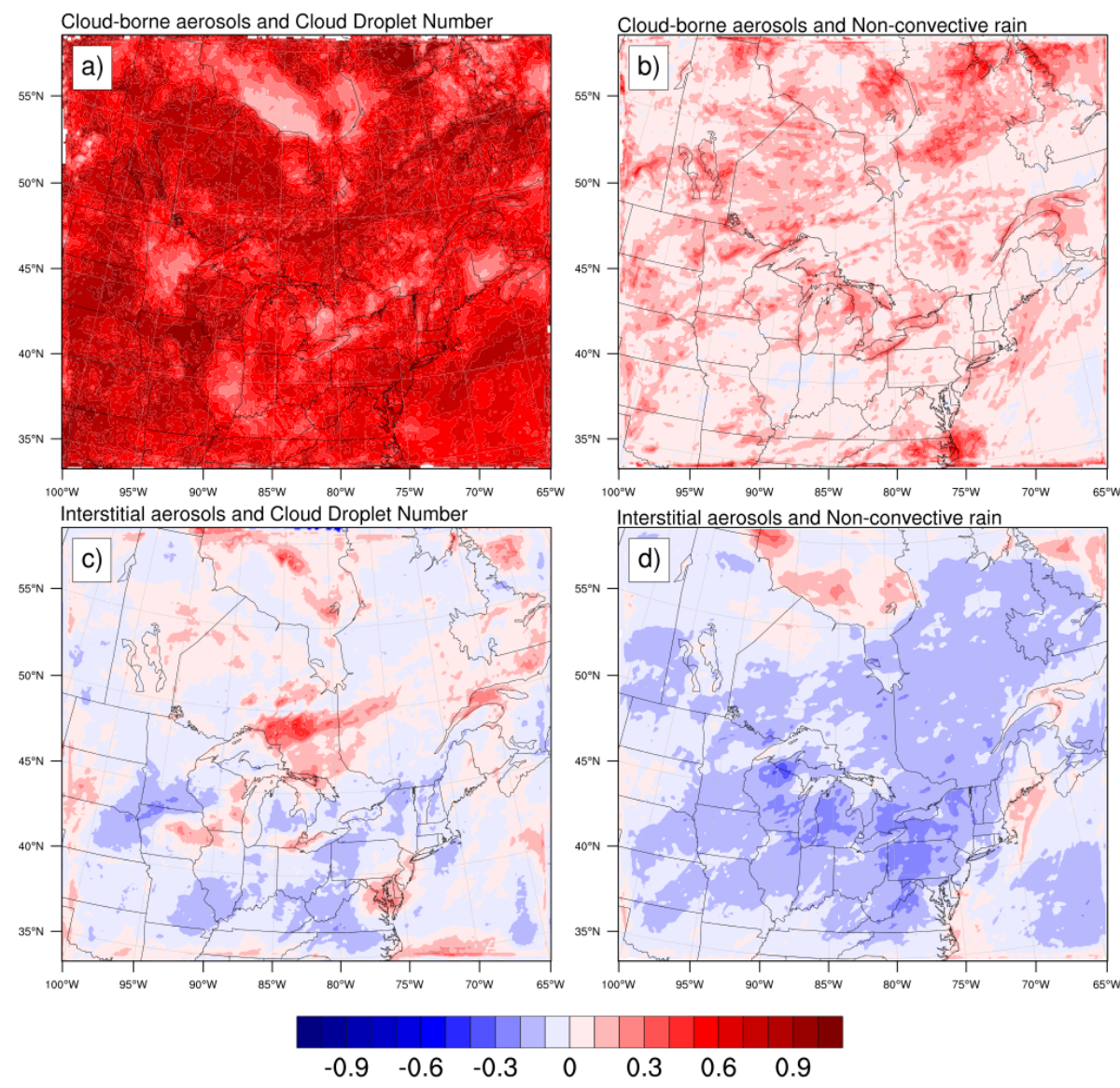

Figure 9. Correlation between simulated WRF/Chem cloud droplet number (left) and non-convective rain (right), with column-integrated cloud-borne (top) and interstitial (bottom) for size range 1-2.5 $\mu \mathrm{m}$.

weaker, correlation also exists between non-convective rain and cloud-borne aerosols of both sizes for similar reasons. There are strong differences, however, in the correlations involving interstitial aerosols of different sizes. Cloud droplet number and non-convective rain both correlate positively with small interstitial aerosols and negatively with larger interstitial particles. The high positive correlation between small interstitial aerosols and cloud droplet number is good evidence that the model reproduces the first indirect aerosol effect - high cloud nucleation rates are caused by the (more numerous) small aerosols. The negative correlation between cloud droplet number and larger interstitial particles suggests that their removal by dissolution into existing cloud droplets is more rapid than their nucleation of new cloud droplets. The correlations involving non-convective rain, strongly positive for small particles and strongly negative for large particles are also consistent with this scenario. The former can be taken as evidence that the cloud droplets nucleated by the small particles eventually grow to produce non-convective precipitation. The latter simply indicates that larger interstitial aerosols are more efficiently removed by precipitation. Short simulations in which wet scavenging was turned off support these statements; the above correlations were weaker for these runs.

These general conclusions are framed in terms of the behaviour on large spatial scales, but the figures show interesting (and significant) deviations at local scales. One of these is the positive correlation between large interstitial aerosols and cloud droplet number that occurs downwind of Lake Superior and Lake Huron and the reduced anti-correlation with non-convective rain that occurs at the same locations. While this is probably a purely physical effect involving the liquid aerosol droplets created by breaking waves at the eastern shores of these very large lakes, it is an interesting demonstration of the ability of WRF/Chem to produce such micrometeorological phenomena.

\section{Conclusions}

Based on WRF/Chem v3.2 simulations with and without chemistry, we conclude that anthropogenic emissions and the related chemistry have a significant effect on precipitation in north-eastern North America. The simulations covered the period from April to August 2009 in a domain with a $12 \mathrm{~km}$ 
horizontal grid resolution; we used temporally and spatially distributed emission fluxes from area, point and mobile sources produced using the SMOKE emission-processing model version 2.7. Evaluation of the results against available surface measurements for various meteorological variables and chemical compositions shows that the model reproduces these measurements reasonably well. We also conclude that our configuration of the models for the domain of interest is suitable for scenario studies of the effects on precipitation of changes in total population and population distribution (as related to consequent changes in aerosols), because the biases we obtain are either smaller than or consistent with those obtained in other published studies using the same models.

The study shows that convective precipitation dominates in the summer and in the southern part of the domain due to greater tropospheric instability in warmer periods. Although cloud-resolved (non-convective) rain contributes much less in total precipitation, it is more significant during in the spring than later in the summer. A systematic over-prediction is obvious in simulated monthly mean total daily rain. This positive bias increases in warmer months as the convective precipitation increases. This appears to be a common problem with the prediction of convective precipitation, which is associated with its high spatial variability. This will have only a secondary effect on the planned scenario studies, however, because these will focus on anthropogenic effects on regional-scale precipitation.

WRF/Chem-WRF difference simulations show that the inclusion of chemistry decreases the convective rain in the southern (warmer) parts of domain and increases it in the northern parts. The reduction can be associated with increased stability due to surface cooling and upper-air warming when chemistry is included, but the spatial variations show that the strength of these effects depends on local meteorology. The inclusion of chemistry results in a small increase in non-convective rain in southern parts of domain and a pronounced increase (around $+30 \%$ ) near the heavily populated urban areas of the US Atlantic coast, which is consistent with the locations of higher $\mathrm{PM}_{2.5}$ concentrations. A high-resolution view of the Atlantic coast shows a strong increase in non-convective rain downwind of heavily populated areas. Small nitrate aerosols in the size range $0.1-1.0 \mu \mathrm{m}$ had the highest spatial correlation with non-convective rain in this region.

Spatial correlation coefficients for activated (cloud-borne) particles and non-activated (interstitial) particles in various size ranges elucidate some of the mechanisms causing these results. A strong positive correlation is found between cloud droplet number and cloud-borne aerosols in both small and large sizes indicating that aerosols nucleate new cloud droplets and dissolve in existing droplets. Also, non-convective rain correlates positively with cloud-borne aerosols of all sizes for the same reason. Small and large non-activated (interstitial) aerosols, however, behave differently. Cloud droplet number and non-convective rain both correlate positively with small interstitial aerosols and both correlate negatively with larger interstitial particles. The positive correlation between small interstitial aerosols and cloud droplet number is consistent with the first indirect aerosol effect. The negative correlation between cloud droplet number and larger interstitial aerosols suggests that they are being removed by dissolution into existing cloud droplets more rapidly than they nucleate new cloud droplets. The strong positive (negative) correlations between small (large) interstitial aerosols and non-convective rain are also consistent with this scenario.

\section{The Supplement related to this article is available online at doi:10.5194/acp-14-5111-2014-supplement.}

Acknowledgements. The authors are grateful to Ontario Power Generation (OPG) and the Natural Sciences and Engineering Research Council (NSERC) of Canada for financial support of this work. We are especially grateful to R. Lyng for helpful comments and suggestions.

Edited by: D. J. Cziczo

\section{References}

Abdul-Razzak, H. and Ghan, S. J.: A parameterization of aerosol activation - 3. Sectional representation, J. Geophys. Res.-Atmos., 107, 4026-4031, doi:10.1029/2001JD000483, 2002.

Ackerman, A. S., Toon, O. B., Stevens, D. E., Heymsfield, A. J., Ramanathan, V., and Welton, E. J.: Reduction of tropical cloudiness by soot, Science, 288, 1042-1047, doi:10.1126/science.288.5468.1042, 2000.

Albrecht, B. A.: Aerosols, Cloud Microphysics, and Fractional Cloudiness, Science, 245, 1227-1230, doi:10.1126/science.245.4923.1227, 1989.

Andreae, M. O., Rosenfeld, D., Artaxo, P., Costa, A. A., Frank, G. P., Longo, K. M., and Silva-Dias, M. A. F.: Smoking rain clouds over the Amazon, Science, 303, 1337-1342, doi:10.1126/science.1092779, 2004.

Auvray, M. and Bey, I.: Long-range transport to Europe: Seasonal variations and implications for the European ozone budget, J. Geophys. Res.-Atmos., 110, 303-325, doi:10.1029/2004JD005503, 2005.

Bell, T. L., Rosenfeld, D., Kim, K. M., Yoo, J. M., Lee, M. I., and Hahnenberger, M.: Midweek increase in US summer rain and storm heights suggests air pollution invigorates rainstorms, J. Geophys. Res.-Atmos., 113, D02209, doi:10.1029/2007JD008623, 2008.

Borys, R. D., Lowenthal, D. H., Cohn, S. A., and Brown, W. O. J.: Mountaintop and radar measurements of anthropogenic aerosol effects on snow growth and snowfall rate, Geophys. Res. Lett., 30, 1538, doi:10.1029/2002GL016855, 2003.

Chapman, E. G., Gustafson Jr., W. I., Easter, R. C., Barnard, J. C., Ghan, S. J., Pekour, M. S., and Fast, J. D.: Coupling aerosol- 
cloud-radiative processes in the WRF-Chem model: Investigating the radiative impact of elevated point sources, Atmos. Chem. Phys., 9, 945-964, doi:10.5194/acp-9-945-2009, 2009.

Chen, F. and Dudhia, J.: Coupling an advanced land surfacehydrology model with the Penn State-NCAR MM5 modeling system. Part I: Model implementation and sensitivity, Mon. Weather Rev., 129, 569-585, doi:10.1175/15200493(2001)129<0569:CAALSH>2.0.Co;2, 2001.

Chen, F., Mitchell, K., Janjic, Z., and Baldwin, M.: Impact of landsurface processes on the NCEP Eta model quantitative precipitation forecast, Special Symposium on Hydrology, 281-282, 1998.

Chou, M. D., Suarez, M. J., Ho, C. H., Yan, M. M. H., and Lee, K. T.: Parameterizations for cloud overlapping and shortwave single-scattering properties for use in general circulation and cloud ensemble models, J. Climate, 11, 202214, doi:10.1175/1520-0442(1998)011<0202:Pfcoas>2.0.Co;2, 1998.

Chuang, M. T., Zhang, Y., and Kang, D. W.: Application of WRF/Chem-MADRID for real-time air quality forecasting over the Southeastern United States, Atmos. Environ., 45, 6241-6250, doi:10.1016/j.atmosenv.2011.06.071, 2011.

Cotton, W. R. and Pielke Sr., R. A.: Human impacts on weather and climate, Cambridge University Press, Cambridge, 2007.

Emmons, L. K., Walters, S., Hess, P. G., Lamarque, J.-F., Pfister, G. G., Fillmore, D., Granier, C., Guenther, A., Kinnison, D., Laepple, T., Orlando, J., Tie, X., Tyndall, G., Wiedinmyer, C., Baughcum, S. L., and Kloster, S.: Description and evaluation of the Model for Ozone and Related chemical Tracers, version 4 (MOZART-4), Geosci. Model Dev., 3, 43-67, doi:10.5194/gmd3-43-2010, 2010.

Fahey, K. M. and Pandis, S. N.: Optimizing model performance: variable size resolution in cloud chemistry modeling, Atmos. Environ., 35, 4471-4478, doi:10.1016/S1352-2310(01)00224-2, 2001

Fast, J. D., Gustafson, W. I., Easter, R. C., Zaveri, R. A., Barnard, J. C., Chapman, E. G., Grell, G. A., and Peckham, S. E.: Evolution of ozone, particulates, and aerosol direct radiative forcing in the vicinity of Houston using a fully coupled meteorology-chemistry-aerosol model, J. Geophys. Res.-Atmos., 111, D21305, doi:10.1029/2005JD006721, 2006.

Givati, A. and Rosenfeld, D.: Quantifying precipitation suppression due to air pollution, J. Appl. Meteorol., 43, 1038-1056, doi:10.1175/1520-0450(2004)043<1038:Qpsdta>2.0.Co;2, 2004.

Grell, G. A. and Devenyi, D.: A generalized approach to parameterizing convection combining ensemble and data assimilation techniques, Geophys. Res. Lett., 29, 1693, doi:10.1029/2002GL015311, 2002.

Grell, G. A., Peckham, S. E., Schmitz, R., McKeen, S. A., Frost, G., Skamarock, W. C., and Eder, B.: Fully coupled "online" chemistry within the WRF model, Atmos. Environ., 39, 6957-6975, doi:10.1016/j.atmosenv.2005.04.027, 2005.

Guenther, A., Karl, T., Harley, P., Wiedinmyer, C., Palmer, P. I., and Geron, C.: Estimates of global terrestrial isoprene emissions using MEGAN (Model of Emissions of Gases and Aerosols from Nature), Atmos. Chem. Phys., 6, 3181-3210, doi:10.5194/acp-63181-2006, 2006.

Gustafson, W. I., Chapman, E. G., Ghan, S. J., Easter, R. C., and Fast, J. D.: Impact on modeled cloud characteristics due to simplified treatment of uniform cloud condensation nuclei during NEAQS 2004, Geophys. Res. Lett., 34, L19809, doi:10.1029/2007GL030021, 2007.

Haywood, J. M. and Boucher, O.: Estimates of the direct and indirect radiative forcing due to tropospheric aerosols: A review, Rev. Geophys., 38, 513-543, doi:10.1029/1999RG000078, 2000.

Haywood, J. M., Ramaswamy, V., and Soden, B. J.: Tropospheric aerosol climate forcing in clear-sky satellite observations over the oceans, Science, 283, 1299-1303, doi:10.1126/science.283.5406.1299, 1999.

Hong, S. Y., Noh, Y., and Dudhia, J.: A new vertical diffusion package with an explicit treatment of entrainment processes, Mon. Weather Rev., 134, 2318-2341, doi:10.1175/MWR3199.1, 2006.

Houyoux, M. R. and Vukovich, J. M.: Updates to the Sparse Matrix Operator Kernel Emissions (SMOKE) Modeling System and Integration with Models-3, The Emission Inventory: Regional Strategies for the Future, Air \& Waste Management Association Raleigh, NC, 1999.

IPCC: Climate changes 2007: the physical sciences basis, in: Contribution of Working Group I to the Fourth Assemssment Report of the Intergovernmental Panel on Climate Change, edited by: Solomon, S., Qin, D., and Manning, M., 2007.

Kessler, E.: On Distribution and Continuity of Water Substance in Atmospheric Circulation, American Meteorological Society, 84 pp., 1969.

Khain, A., Arkhipov, V., Pinsky, M., Feldman, Y., and Ryabov, Y.: Rain enhancement and fog elimination by seeding with charged droplets. part I: Ttheory and numerical simulations, J. Appl. Meteorol., 43, 1513-1529, doi:10.1175/JAM2131.1, 2004.

Khain, A., Rosenfeld, D., and Pokrovsky, A.: Aerosol impact on the dynamics and microphysics of deep convective clouds, Q. J. Roy Meteor. Soc., 131, 2639-2663, doi:10.1256/QJ.04.62, 2005.

Koren, I., Kaufman, Y. J., Rosenfeld, D., Remer, L. A., and Rudich, Y.: Aerosol invigoration and restructuring of Atlantic convective clouds, Geophys. Res. Lett., 32, L14828, doi:10.1029/2005GL023187, 2005.

Lin, Y. L., Farley, R. D., and Orville, H. D.: Bulk Parameterization of the Snow Field in a Cloud Model, J. Clim. Appl. Meteorol., 22, 1065-1092, doi:10.1175/15200450(1983)022<1065:Bpotsf>2.0.Co;2, 1983.

Liu, Y. G., Daum, P. H., and McGraw, R. L.: Size truncation effect, threshold behavior, and a new type of autoconversion parameterization, Geophys. Res. Lett., 32, L11811, doi:10.1029/2005g1022636, 2005.

Lohmann, U. and Feichter, J.: Global indirect aerosol effects: a review, Atmos. Chem. Phys., 5, 715-737, doi:10.5194/acp-5-7152005, 2005.

Lohmann, U. and Hoose, C.: Sensitivity studies of different aerosol indirect effects in mixed-phase clouds, Atmos. Chem. Phys., 9, 8917-8934, doi:10.5194/acp-9-8917-2009, 2009.

Lynn, B., Khain, A., Rosenfeld, D., and Woodley, W. L.: Effects of aerosols on precipitation from orographic clouds, J. Geophys. Res.-Atmos., 112, D10225, doi:10.1029/2006JD007537, 2007.

McKeen, S., Chung, S. H., Wilczak, J., Grell, G., Djalalova, I., Peckham, S., Gong, W., Bouchet, V., Moffet, R., Tang, Y., Carmichael, G. R., Mathur, R., and Yu, S.: Evaluation of several $\operatorname{PM}(2.5)$ forecast models using data collected during the ICARTT/NEAQS 2004 field study, J. Geophys. Res.-Atmos., 112, D10S20, doi:10.1029/2006JD007608, 2007. 
Mlawer, E. J., Taubman, S. J., Brown, P. D., Iacono, M. J., and Clough, S. A.: Radiative transfer for inhomogeneous atmospheres: RRTM, a validated correlated-k model for the longwave, J. Geophys. Res.-Atmos., 102, 16663-16682, doi:10.1029/97JD00237, 1997.

Ntelekos, A. A., Smith, J. A., Donner, L., Fast, J. D., Gustafson, W. I., Chapman, E. G., and Krajewski, W. F.: The effects of aerosols on intense convective precipitation in the northeastern United States, Q. J. Roy Meteor. Soc., 135, 1367-1391, doi:10.1002/QJ.476, 2009.

Peckham, S., Grell, G., McKeen, S., Barth, M., Pfister, G. G., Wiedinmyer, C., Fast, J. D., Gustafson, W. I., Zaveri, R. A., Easter, R. C., Barnard, J. C., Chapman, E. G., Hewson, M., Schmitz, R., Salzmann, M., and Freitas, S.: WRF/Chem Version 3.3 User's Guide. NOAA Technical Memo., 98 pp., 2011.

Penner, J. E., Dong, X. Q., and Chen, Y.: Observational evidence of a change in radiative forcing due to the indirect aerosol effect, Nature, 427, 231-234, doi:10.1038/Nature02234, 2004.

Ramanathan, V., Crutzen, P. J., Kiehl, J. T., and Rosenfeld, D.: Atmosphere - Aerosols, climate, and the hydrological cycle, Science, 294, 2119-2124, doi:10.1126/science.1064034, 2001.

Rosenfeld, D.: Suppression of rain and snow by urban and industrial air pollution, Science, 287, 1793-1796, doi:10.1126/science.287.5459.1793, 2000.

Rosenfeld, D. and Givati, A.: Evidence of orographic precipitation suppression by air pollution-induced aerosols in the western United States, J. Appl. Meteorol. Clim., 45, 893-911, doi:10.1175/JAM2380.1, 2006.

Rosenfeld, D., Lahav, R., Khain, A., and Pinsky, M.: The role of sea spray in cleansing air pollution over ocean via cloud processes, Science, 297, 1667-1670, doi:10.1126/science.1073869, 2002.

Rosenfeld, D., Kaufman, Y. J., and Koren, I.: Switching cloud cover and dynamical regimes from open to closed Benard cells in response to the suppression of precipitation by aerosols, Atmos. Chem. Phys., 6, 2503-2511, doi:10.5194/acp-6-2503-2006, 2006.

Rosenfeld, D., Lohmann, U., Raga, G. B., O’Dowd, C. D., Kulmala, M., Fuzzi, S., Reissell, A., and Andreae, M. O.: Flood or drought: How do aerosols affect precipitation?, Science, 321, 1309-1313, doi:10.1126/science.1160606, 2008.

Rudich, Y., Khersonsky, O., and Rosenfeld, D.: Treating clouds with a grain of salt, Geophys. Res. Lett., 29, 2060, doi:10.1029/2002GL016055, 2002.

Saide, P. E., Spak, S. N., Carmichael, G. R., Mena-Carrasco, M. A., Yang, Q., Howell, S., Leon, D. C., Snider, J. R., Bandy, A. R., Collett, J. L., Benedict, K. B., de Szoeke, S. P., Hawkins, L. N., Allen, G., Crawford, I., Crosier, J., and Springston, S. R.: Evaluating WRF-Chem aerosol indirect effects in Southeast Pacific marine stratocumulus during VOCALS-REx, Atmos. Chem. Phys., 12, 3045-3064, doi:10.5194/acp-12-3045-2012, 2012.

Shaw, W. J., Allwine, K. J., Fritz, B. G., Rutz, F. C., Rishel, J. P., and Chapman, E. G.: Evaluation of the wind erosion module in DUSTRAN, Atmos. Environ., 42, 1907-1921, doi:10.1016/j.atmosenv.2007.11.022, 2008.

Tao, W. K., Li, X. W., Khain, A., Matsui, T., Lang, S., and Simpson, J.: Role of atmospheric aerosol concentration on deep convective precipitation: Cloud-resolving model simulations, J. Geophys. Res.-Atmos., 112, D24S18, doi:10.1029/2007JD008728, 2007.
Taubman, B. F., Marufu, L. T., Vant-Hull, B. L., Piety, C. A., Doddridge, B. G., Dickerson, R. R., and Li, Z. Q.: Smoke over haze: Aircraft observations of chemical and optical properties and the effects on heating rates and stability, J. Geophys. Res.-Atmos., 109, D02206, doi:10.1029/2003JD003898, 2004.

Tuccella, P., Curci, G., Visconti, G., Bessagnet, B., Menut, L., and Park, R. J.: Modeling of gas and aerosol with WRF/Chem over Europe: Evaluation and sensitivity study, J. Geophys. Res.Atmos., 117, D03303, doi:10.1029/2011JD016302, 2012.

Twomey, S. A.: Pollution and Cloud Albedo, Eos T. Am. Geophys. Un., 58, 797-797, 1977.

Wang, K., Zhang, Y., Jang, C., Phillips, S., and Wang, B. Y.: Modeling intercontinental air pollution transport over the transPacific region in 2001 using the Community Multiscale Air Quality modeling system, J. Geophys. Res.-Atmos., 114, D04307, doi:10.1029/2008JD010807, 2009.

Wild, O., Zhu, X., and Prather, M. J.: Fast-j: Accurate simulation of in- and below-cloud photolysis in tropospheric chemical models, J. Atmos. Chem., 37, 245-282, doi:10.1023/A:1006415919030, 2000 .

Williams, E., Rosenfeld, D., Madden, N., Gerlach, J., Gears, N., Atkinson, L., Dunnemann, N., Frostrom, G., Antonio, M., Biazon, B., Camargo, R., Franca, H., Gomes, A., Lima, M., Machado, R., Manhaes, S., Nachtigall, L., Piva, H., Quintiliano, W., Machado, L., Artaxo, P., Roberts, G., Renno, N., Blakeslee, R., Bailey, J., Boccippio, D., Betts, A., Wolff, D., Roy, B., Halverson, J., Rickenbach, T., Fuentes, J., and Avelino, E.: Contrasting convective regimes over the Amazon: Implications for cloud electrification, J. Geophys. Res.-Atmos., 107, 8082, doi:10.1029/2001jd000380, 2002.

Wu, S. Y., Krishnan, S., Zhang, Y., and Aneja, V.: Modeling atmospheric transport and fate of ammonia in North Carolina - Part I: Evaluation of meteorological and chemical predictions, Atmos. Environ., 42, 3419-3436, doi:10.1016/j.atmosenv.2007.04.031, 2008.

Xue, Y., Zeng, F. J., Mitchell, K. E., Janjic, Z., and Rogers, E.: The impact of land surface processes on simulations of the US hydrological cycle: A case study of the 1993 flood using the SSiB land surface model in the NCEP Eta regional model, Mon. Weather Rev., 129, 2833-2860, doi:10.1175/15200493(2001)129<2833:Tiolsp>2.0.Co;2, 2001.

Yang, Q., W. I. Gustafson Jr., Fast, J. D., Wang, H., Easter, R. C., Morrison, H., Lee, Y.-N., Chapman, E. G., Spak, S. N., and Mena-Carrasco, M. A.: Assessing regional scale predictions of aerosols, marine stratocumulus, and their interactions during VOCALS-REx using WRF-Chem, Atmos. Chem. Phys., 11, 11951-11975, doi:10.5194/acp-11-11951-2011, 2011.

Yerramilli, A., Challa, V. S., Dodla, V. B. R., Dasari, H. P., Young, J. H., Patrick, C., Baham, J. M., Hughes, R. L., Hardy, M. G., and Swanier, S. J.: Simulation of Surface Ozone Pollution in the Central Gulf Coast Region Using WRF/Chem Model: Sensitivity to PBL and Land Surface Physics, Adv. Meteorol., 2010, 319138 , doi:10.1155/2010/319138, 2010.

Zaveri, R. A. and Peters, L. K.: A new lumped structure photochemical mechanism for large-scale applications, J. Geophys. Res. Atmos., 104, 30387-30415, doi:10.1029/1999JD900876, 1999.

Zaveri, R. A., Easter, R. C., Fast, J. D., and Peters, L. K.: Model for Simulating Aerosol Interactions and Chemistry (MOSAIC), J. Geophys. Res., 113, D13204, doi:10.1029/2007JD008782, 2008. 
Zhang, Y., Wen, X. Y., and Jang, C. J.: Simulating chemistryaerosol-cloud-radiation-climate feedbacks over the continental US using the online-coupled Weather Research Forecasting Model with chemistry (WRF/Chem), Atmos. Environ., 44, 3568-3582, doi:10.1016/j.atmosenv.2010.05.056, 2010a.
Zhang, Y., Olsen, S. C., and Dubey, M. K.: WRF/Chem simulated springtime impact of rising Asian emissions on air quality over the US, Atmos. Environ., 44, 2799-2812, doi:10.1016/j.atmosenv.2010.05.003, $2010 \mathrm{~b}$. 